The Chittagong Univ. J. B. Sci., Vol. 5(1 \&2):155-157, 2010.

SHORT COMMUNICATION

\title{
PESTICIDE RESIDUES IN WATER SAMPLES OF SOME PADDY FIELDS IN NARAYANGONJ
}

The surface water bodies have become very much susceptible to pollution by pesticides due to their increased application in agriculture. Indiscriminate use of pesticides for increased crop production leads to the contamination of surface water by run off (Sarkara 2007). The quality of water is very important for agriculture, domestic, municipal and industrial uses. It is suspected that due to agricultural practices, especially increased use of chemical fertilizers and pesticides, water quality problems might have arisen under irrigated areas in Bangladesh as well.

Therefore, the occurrence of agricultural pesticides in water represents a threat to public health and environment. Use of pesticides has to be controlled to avoid contamination of food supplies and water matrix, but present measures in Bangladesh are inadequate and farmers rarely implement standards, allowing sale of unregistered pesticides and misuse (Matin et al. 1998). On this background the present work was undertaken to observe the pesticide residues in some water samples from agricultural fields around Narayanganj, Bangladesh. Twenty surface water samples were collected from the most vulnerable sites of paddy fields at Pagla in Narayangonj. Water samples in glass containers were carried to the laboratory of the Agrochemical and Environmental Research Division, Institute of Food \& Radiation Biology, Savar as quickly as possible and kept in refrigerator until extraction. Water sample was extracted with double distilled hexane. The combined hexane extract treated with 5-g anhydrous sodium sulphate to remove traces of water was evaporated in rotary vacuum evaporator to a small volume under a mild stream of nitrogen. Clean up was carried out according to DFG (1987). Organochlorine pesticide residues were analyzed by gas chromatograph (GC/ECD) and organophosphorus as well as carbamate pesticides by High Performance Liquid Chromatography (HPLC). 
CHOWDHURY ET AL..

TABLE 1: AMOUNT OF ORGANOPHOSPHORUS \& CARBAMATE PESTICIDE RESIDUES IN WATER SAMPLES OF PAGLA, NARAYANGONJ

\begin{tabular}{ccc}
\hline $\begin{array}{c}\text { Sample } \\
\text { No. }\end{array}$ & Organophosphorus & Carbamate \\
\cline { 2 - 3 } & $\begin{array}{c}\text { Diazinon } \\
(\mathrm{ppb})\end{array}$ & $\begin{array}{c}\text { Carbofuran } \\
(\mathrm{ppb})\end{array}$ \\
\hline WS2 & 0.693 & $\mathrm{ND}$ \\
WS4 & $\mathrm{ND}$ & 0.276 \\
WS6 & 2.144 & $\mathrm{ND}$ \\
WS8 & $\mathrm{ND}$ & 2.181 \\
WS10 & 1.062 & 1.062 \\
WS12 & $\mathrm{ND}$ & 1.218 \\
WS16 & 0.390 & $\mathrm{ND}$ \\
WS18 & $\mathrm{ND}$ & 0.252 \\
\hline
\end{tabular}

$\mathrm{WS}=$ Water Sample, ND $=$ Not Detected, Detection Limit $=0.01 \mathrm{ppb}$

Water samples contained no organochlorine pesticide residues except Diazinon (organophosphorous) and carbofuran (carbamate) and their levels were within the FAO/WHO guideline values. Four samples (WS2, WS6, WS10 and WS16) were found to be contaminated with residues of diazinon and five samples (WS4, WS8, WS10, WS12 and WS18) with carbofuran (Table 1) but the residue levels of diazinon ranged from $0.390 \mathrm{ppb}$ (WS16) to $2.144 \mathrm{ppb}$ (WS6) and of carbofuran from $0.252 \mathrm{ppb}$ (WS18) to $2.181 \mathrm{ppb}$ (WS8). All the values were within the FAO/WHO guideline limits. Water samples did not contain any organochlorine residues like DDT and its metabolites as well as chlorpyriphos, carbaryl, fenitrothion, malathion (organophosphorus pesticides). Most samples contained pesticide residues below detection limit (0.01 ppb). Matin et al. (1998) also stated that DDT, DDE and dieldrin were present in some surface water samples of the irrigated crop fields at Gaibandha, and in most cases, their levels were found to be within WHO guideline values for drinking water quality (WHO 1993). Alam et al. (1999) found the maximum amount of DDT as $5.7 \mu \mathrm{g} / \mathrm{L}$ and 
PESTICIDE RESIDUES IN WATER SAMPLES OF PADDY FIELDS

lindane as $5.084 \mu \mathrm{g} / \mathrm{L}$ in the water samples collected from Meghna-Dhanogoda irrigation project. but in the present study, there was no trace of organochlorine pesticides in water.

\section{REFERENCES}

ALAM, M.M., DAS, N.G., RAHMAN, M.M. AND MALEK, M.A. 1999. Organochlorine insecticide residues in water and soil of the Meghna Dhonagoda irrigation project of Bangladesh. J. Asiat. Soc. Bangladesh, Sci. 25(1): 132-142.

DFG 1987. MANUAL OF PESTICIDE RESIDUE ANALYSIS. Pesticide Commission, Weinheim, New York, NY: VCH. 1: 297-307.

SARKARA, B, VENKATESWRALUB, N., RAOB,R.N., BHATTACHARJEEC, C., KALEA,V., 2007.Treatment of pesticide contaminated surface water for production of potable water by acoagulation-adsorption-nanofiltration approach Available at http:// www. aseanenvironment. info/ Abstract/ 41015473.pdf. 2007 Elsevier

MATIN, M. A., MALEK, M.A., AMIN, M.AHMAN, S., KHATOON, J., RAHMAN, M., AMIN UDDIN, M. AND MIAH, A.J. 1998. Organochlorine insecticide residues in surface and underground water from different regions of Bangladesh. Agric. Ecosys. and Environ. 69: 11-15.

WHO (World Health Organization). 1993. Guidelines for drinking water quality, $2^{\text {nd }}$ edn. vol.1, (Recommendation). Geneva, Switzerland. M. ALAMGIR Z. CHOWDHURY ${ }^{1}$ *, M. AMIN UDDIN ${ }^{1}$, M.TIPU SULTAN ${ }^{2}$,
M. HASANUZZAMAN ${ }^{1}$, M. AINUL HOQUE AND M.A.ZAMAN $^{3}$

${ }^{1}$ Institute of Food and Radiation Biology (IFRB), Gonakbari, Savar, GPO Box-3787,

Dhaka-1000, ${ }^{2}$ Dept. of Applied Nutrition and Food Technology, Islamic University, Kushtia-

7003, ${ }^{3}$ Dept. of Soil Science, University of Chittagong, Chittagong

* Corresponding author : Senior Scientific Officer, Intstitute of Food \& Radiation Biology, Atomic Energy Research Establishment. Ganakbari, Savar, G.P.O BOX 3787, Dhaka-1000,

Manuscript received on 1. 6. 2010; Accepted on 29.9.11

The Chittagong University Journal of Biological Sciences, Vol. 5 (1 \& 2). Page No:155-157 